\title{
Surrealismo e infância em Bandeira Preta, de Branquinho da Fonseca
}

\author{
Surrealism and childhood in Bandeira Preta, by Branquinho da Fonseca
}

\author{
KeLI CRISTINA PACHECO \\ Universidade Estadual de Ponta Grossa - Ponta Grossa - Paraná - Brasil \\ MARCELO WASELCOSKI \\ Faculdades SECAL - Ponta Grossa - Paraná - Brasil
}

-

\begin{abstract}
Resumo: Este estudo apresenta uma leitura descritiva e analítica dos contos "Bandeira Preta", "Jurro" e "Um peixe Gordo", reunidos na obra Bandeira Preta, de Branquinho da Fonseca. O objetivo é investigar a permanência da presença de uma preocupação inicial do programa surrealista nos contos do autor, que se evidencia no enfoque temático da transição da infância para a idade adulta. A linguagem poética adotada por Branquinho da Fonseca compõe um enredo desenvolvido através dos olhos infantis das personagens, criando um singular universo ficcional. As crianças, em estado de poesia, arquitetam as ações em uma atmosfera surrealista, e desta forma a infância surge como uma fase naturalmente transgressora, que culmina em um confronto com as práticas autoritárias do mundo adulto.
\end{abstract}

Palavras-chave: Branquinho da Fonseca; Contos; Surrealismo; Infância

\begin{abstract}
This study presents a descriptive and analytical reading of short stories titled "Bandeira Preta", "Jurro" and "Um peixe gordo", in Bandeira Preta work of Branquinho da Fonseca. The objective is to identify the presence of an initial concern of the surrealist program in tales of the author. The stories are about the transition from childhood to adulthood. The poetic language composes a storyline developed through childlike eyes of the characters, creating a singular fictional universe. Children in the state of poetry invent actions in a surreal atmosphere, and thus childhood arises naturally as a transgressive phase, culminating in a confrontation with the authoritarian practices of the adult world.
\end{abstract}

Keywords: Branquinho da Fonseca; Short Stories; Surrealism; Childhood

Ainda pouco lido no Brasil, o autor português Branquinho da Fonseca (1905-1974), como ficou conhecido, foi dramaturgo, poeta, contista, romancista e um dos fundadores da revista Presença, onde teve seu primeiro texto dramático publicado, Posição de Guerra (1928). Fonseca fundou também as revistas Tríptico e Sinal, esta última com Miguel Torga, contudo logo após, no ano de 1930, rompeu com o grupo presencista. ${ }^{1}$

Antes, em 1927, Branquinho da Fonseca, João Gaspar Simões e José Régio, fundam e dirigem a revista intitulada Coimbrã Presença, considerado espaço de

\footnotetext{
1 Usando o pseudônimo de Antônio Bandeira publica, em 1942, o livro $O$ Barão, considerado sua obra prima, segundo estudiosos. Este juntamente às obras Rio Turvo e Bandeira Preta compõem seus contos de maturidade. (cf. FADDA, 1983:176), sendo que em Rio Turvo e Bandeira Preta o autor já utilizou seu verdadeiro nome.
}

divulgação do modernismo em Portugal. Fernando Paulo Rosa Dias, em "A teoria da 'Presença", divide em cinco linhas a teoria presencista:

[...] são cinco linhas de orientação da teoria presencista que resgatávamos:

1. A Liberdade Individual

2. A Sinceridade Espontânea

3. A Pureza Infantil

4. Intuição e Inconsciente

5. A Deformação (DIAS, 2010:159)

Nas divisões atribuídas por Dias em relação à orientação da revista Presença delineia-se a inclinação surrealista do periódico, assim procuraremos comprovar, neste estudo, que embora Branquinho da Fonseca tenha rompido com o grupo presencista, em 1930, o autor 
continuava influenciado por elementos presentes no fundamento do programa surrealista, como explicitaremos mais adiante. ${ }^{2}$

Em grande parte da sua vida Branquinho da Fonseca viveu condicionado ao regime político totalitário, chamado de Estado Novo, em Portugal, forma de governo que sabidamente perdurou entre 1933 e 1974, e vivenciou o domínio português em territórios africanos. Esse contexto político repressivo certamente interferiu no âmbito social e cultural, bem como na obra de Branquinho da Fonseca. Paz afirma que, em contexto como esses, a presença de aspectos surrealistas representa: "[...] um protesto contra a esterilidade espiritual do espírito geométrico, coincidem com revoluções que se transformam em ditaduras cesáreas ou burocráticas, e por fim procuram transcender razão e religião e fundar assim um novo sagrado" (PAZ, 1996:87).

$\mathrm{Na}$ narrativa de Branquinho da Fonseca vemos que a infância representa uma espécie de resistência diante de elementos normativos da sociedade adulta, ou dos que se declaram "possuidores da experiência" (os adultos). Walter Benjamin, em Reflexões sobre a criança, o brinquedo e a educação, já observara que, em oposição à resistência natural da infância, o adulto constrói uma máscara impassível em torno da autoridade incontestável da experiência. Diante dessa autoridade, para o filósofo, a criança fica à margem. Ainda para Benjamim a máscara do adulto, ou a experiência, é inexpressiva, impenetrável, sempre a mesma, portanto oposta ao universo infantil.

As reflexões de Benjamin sobre a infância se assemelham bastante ao que apresentam os surrealistas em primeiro manifesto, como veremos adiante. Vale lembrar que o filósofo admirava profundamente o movimento surrealista na Europa, considerando-o o último movimento de inteligência do continente. Em ensaio publicado em 1929, Benjamin ressalta que no início, "quando irrompeu sobre os criadores sob a forma de uma vaga inspiradora de sonhos, ele [o surrealismo] parecia integral, definitivo, absoluto" (BENJAMIN, 1994:22). E não será gratuita a menção em seu ensaio à "criança terrível", ao jovem poeta Arthur Rimbaud, como autor do texto original representativo ao programa surrealista.

\footnotetext{
2 Ainda em relação a este contato da sua obra com o surrealismo, Massaud Moisés já sugerira que: “[...] sobretudo nos contos, que Branquinho da Fonseca atingiu a posição de relevo que ostenta nos quadros da moderna Literatura Portuguesa. Inserido no movimento da Presença, o seu mundo ficcional caracteriza-se pela tendência introspectiva e intelectualista, próxima das correntes de vanguarda [...]. Fundindo o real e o ideal, o universo das formas sensíveis com as formas intuíveis, o escritor cria um surrealismo poético, que emana da própria sondagem no interior das realidades palpáveis" (MOISES, 2008:368-369, grifo nosso). No excerto acima vemos que Moisés sugestiona a permanência da poética surrealista, buscaremos, portanto, tal presença na obra Bandeira Preta, observando o universo ficcional que essa vanguarda permitiu criar, através das personagens e suas ações, intimamente ligadas ao meio em que estão em contato, reforçadas pela linguagem utilizada pelo narrador, manifestando isto que Moisés denominou surrealismo poético.
}

Vitorino Nemésio, ao tratar da linguagem nas narrativas de Branquinho da Fonseca, escreve: "O mundo real e o imaginário, cada um dos quais ao mesmo tempo contém o outro: o sonho é sonhado no vivido." (NEMÉSIO apud FADDA, 1983:176). Tal sentença representa o confronto do universo das crianças com o adulto, pois diferente do sonho tradicional, de caráter utópico, o sonho das personagens infantis de Fonseca partem da materialidade, irrompem do vivido e esta imagem, nos parece, resume a atmosfera em que se desenvolvem os enredos dos contos do autor, notadamente os que compõem Bandeira Preta. As personagens dos contos analisados sonham somente a partir do contato com a realidade, obviamente ficcional, em que estão imersas. Como exemplo citamos o fragmento do conto "Bandeira Preta", que abre o livro homônimo:

D. Pedro, capitão, com seu livro de bordo aberto a folhas tantas, olhou o céu e tomou nota [...]. O piloto Chinca safava o calebre que prendia o veloz Falcão a um velho choupo da margem frondosa. Rente às águas tranquilas passou, como uma seta, vermelho, azul, e verde um pica-peixe deslumbrante. Com a tripulação em continência, a prima Leonor, atados em rabo de cavalo os cabelos de oiro, içou a bandeira preta no topo do mastro grande. Era uma bandeira quadrada, que tinha ao centro, por suas mãos bordados a retrós branco, um pistolão de boca larga e uma espada recurva, mais imitante a alfanje moiro do que a durindana cristã. [...] Mal aparelhado em sua carpintaria grossa, o Falcão [...] dava bem para quatro pessoas, embora fosse prudente reduzir a tripulação, quando se ia em mira de presa volumosa [...] (FONSECA, 1966:11-12)

O fragmento acima exemplifica como as crianças transformam sua simples embarcação em algo muito maior. Esse contato com a matéria, livro de bordo, bandeira, etc., produz uma vivência que as personagens incorporam com grande seriedade. O sonho aqui, como nos ensinou Nemésio, é "sonhado no vivido".

A obra Bandeira Preta, escrita em 1956, é composta por uma reunião de contos, em que as personagens Pedro, Chinca e Leonor passam por situações, ou as desencadeiam, apresentando a infância como uma fase naturalmente transgressora e intensa. A afirmação já citada de Nemésio indica que através da linguagem, e aqui acrescentamos em contato com ideário surrealista, a obra de Fonseca faz o real e imaginário coexistirem, interpenetrarem-se. $\mathrm{O}$ fragmento abaixo retirado do Manifesto Surrealista, de 1924, de André Breton, orienta ainda para uma ausência do racionalismo e da moral:

Surrealismo, automatismo psíquico puro pelo qual se propõe exprimir, seja verbalmente, seja por escrito, seja de qualquer outra maneira, o funcionamento real do pensamento. Ditado do pensamento, na ausência de todo controle exercido pela razão, fora de toda preocupação estética ou moral. (BRETON, 1978:185) 
O universo ficcional apresentado através das ações das personagens diante da atmosfera criada nos enredos por elas mesmas, como sugere o narrador, instituído da linguagem surreal, caracterizam o universo surrealista proposto por Breton no fragmento acima. Relacionando o surrealismo à literatura, Breton faz ainda uma importante crítica ao método tradicional pelo qual um autor compõe uma personagem:

O autor pega-se com uma personagem, e escolhido este faz peregrinar-se pelo mundo. Haja o que houver este herói cujas ações são admiravelmente previstas tem a incumbência de não desmanchar, parecendo porém sempre desmanchar, os cálculos de que é objeto. As vagas da vida podem parecer arrebatá-lo, rodá-lo, afundá-lo, ele sempre dependerá deste tipo humano formado. (BRETON, 1978:172)

Breton, de certa forma, propõe que se mate o autor para se atribuir vida à personagem, e isso permite o rompimento com o previsível advindo da verdadeira expressão originada pela imprevisibilidade pura, como Breton intitula: "surrealismo, o novo modo de expressão pura [...]" (BRETON, 1978:185), pois vem livre do encargo de obedecer às regras, estilos ou formas. Essa inspiração engloba o sujeito e todo o mundo a sua volta, ou melhor, da relação entre o ser e o meio, e no caso de um enredo, entre personagem e cena. O surrealismo busca a relação do homem com o mundo em matéria e alma, a visão da esfera em que ele está inserido em tons líricos, pela observação do mundo em um estado de poesia, como afirma Otávio Paz: "Surrealista [...] - Transformar a vida em poesia e operar assim uma revolução decisiva nos espíritos, nos costumes e na vida social." (PAZ, 1996:82), somente assim o homem conseguiria transcender o estado inerte recorrente da rotina habitual, transformando-se e vivenciando sua realidade, tornando a vida menos massacrante. E quando transpomos isso para o universo da literatura, há a necessidade da adequação da linguagem, compreendida como fundamento do enredo.

A quebra com a realidade não significa o viver no mundo dos sonhos e sim viver o sonho a partir do mundo. Transpondo isto para o ideário surrealista, nela o narrador procura utilizar-se de como a personagem, sempre informe, vê o seu mundo e relaciona-se com ele, permitindo construí-lo a sua maneira e vivê-lo. Assim há um esforço para isolar do seu viver, da personagem, a "experiência", pois esta acaba remetendo a respostas prontas e sempre as mesmas, criadas e vividas durante a vida, como Walter Benjamin afirma: “[...] vem a grande 'experiência', anos de compromisso, pobreza de ideias, lassidão. Assim é a vida, dizem os adultos, eles já experimentaram isso." (BENJAMIN, 2002:22)
Quando condicionada ao previsível, a personagem torna-se uma repetição constante de seus atos, condenada a perder o olhar lírico sobre as coisas singelas. No revés do previsível está a imagem, diz Breton:

A imagem é uma criação pura do espírito. Ela não pode nascer da comparação, mas da aproximação de duas realidades, mais ou menos remotas. Quanto mais longínquas e justas forem às afinidades de duas realidades próximas, tanto será mais forte a imagem... (BRETON, 1978:182)

O olhar da criança nesse contexto é fundamental, ela possui a autenticidade do informe, pois ainda não está condicionada à "experiência" do adulto. André Breton visualiza na infância uma potência. No Manifesto Surrealista a infância é tema constante e considerada ponto de vista surrealista por natureza:

O espírito que mergulha no surrealismo revive com exaltação a melhor parte de sua infância. Representa para ele um pouco a certeza de que, estando a ponto de se aborrecer, repassa ao menos por um minuto, todo o intransponível de sua vida. [...] Das recordações da infância e de algumas outras se desprenderá um sentimento não-monopolista e em seguida de desviamento que eu considero o mais fecundo que existe. Talvez seja a infância o que mais se aproxima da "verdadeira vida"; a infância além da qual o homem não dispõe, além do seu salvo conduto, senão de algumas entradas a favor; a infância onde tudo concorria, entretanto, para a posse eficaz, e sem acasos, de si mesmo. Graças ao surrealismo, parece que essas oportunidades voltam. (BRETON, 1978:197).

Em Bandeira Preta as personagens infantis vivem um mundo projetado ludicamente, suas imaginações e expressões puras permitem o viver sonhado dentro do "mundo real" do enredo. O estado de poesia, o lirismo, o lado informe da criança, a expressão pura, unidas ao desejo, à busca do amor, e ao erotismo atrelado à figura da mulher compõem alguns dos elementos que constroem o universo surrealista. Porém, vale lembrar que estes são também temas presentes no programa Romântico, mas sobre tal semelhança Paz elucida: "[...] a consciência histórica dos surrealistas é mais clara e profunda e sua relação com o mundo é mais direta e arrojada. Os românticos terminam negando a história e refugiandose no sonho [...]" (PAZ, 1996:87). E, como evidenciase nos excertos citados neste artigo, é possível perceber que, através da linguagem, Branquinho da Fonseca insere esses elementos dentro da sua ficção, ou melhor, a relação com o mundo, como Paz citou, é constante na construção dos enredos, fazendo com que as personagens vivam o sonho e não se refugiem nele. 
O enredo do conto "Bandeira Preta" inicia com as personagens Pedro, Chinca e Leonor, embarcando em uma viagem de saques à quinta do pai de Pedro, tais feitos tinham como objetivo ajudar o senhor Paulo no seu sustento, o velho ermitão, outrora palhaço, era admirado pelas crianças. O conto termina com a peripécia que Pedro faz auxiliado por seus cúmplices, quando pinta um diabo com massa de fósforos na porta da casa do Senhor Prior, causando um enorme alvoroço no vilarejo onde viviam.

No conto "Jurro", o antagonista, personagem que intitula o conto, trabalha como vigia de uma quinta. Jurro fere a mão de Pedro, ação que desencadeia todo o enredo, levando as três personagens, Jurro, Pedro, e Chinca, a prestarem esclarecimentos na delegacia. Jurro, saindo da delegacia, segue pela rua sozinho até se deparar com uma taverna aberta, adentrando-a envolve-se em uma nova confusão, resultando na sua morte.

O último que iremos analisar chama-se "Um Peixe Gordo", este é o conto que encerra a obra Bandeira Preta. Nele Pedro e Chinca, em idade adulta, revelam o desejo pelo sexo oposto. O enredo se inicia quando as personagens combinam uma pescaria, Chinca na espera de Pedro acaba encontrando a velha "Nau Falcão", a desvira e parte para a pescaria sem o companheiro que demorava a chegar. Chinca depara-se com as lavadeiras que lhe pedem um peixe gordo, então o jovem vai à busca do peixe e, em um de seus mergulhos, morre.

A presença da análise do narrador nos contos é necessária, pois através dele é que temos acesso ao cenário e personagens dos enredos. É através do narrador que, obviamente, conhecemos as personagens, suas personalidades e pensamentos, além de compreendermos como estas estabelecem a relação com o mundo ficcional, ou entre "objeto e sujeito", e tal relação é fundamental para o estabelecimento da atmosfera surrealista, como Paz afirma: "[...] os surrealistas atacam as noções de objeto e sujeito." (PAZ, 1996:87). A relação das personagens com objetos, com o meio, com as personagens, enfim, como um todo para realização dos contos são descritas e minuciosamente detalhadas, e a atmosfera surrealista necessita de um trato especial de tais elementos.

Em uma primeira análise poderíamos pensar que os contos são narrados em heterodiegese, porém não podemos deixar de observar que o narrador delineia os protagonistas: "Chinca, com a mão de conhecedor, cortou uma espiga..." (FONSECA, 1966:14) e, além disso, faz inferências explicitando, quando utiliza a expressão "mão de conhecedor", marcada por vírgulas na frase, enfatizando a sua opinião, mas que nasce do contato da personagem com a matéria. E também no fragmento que se segue: "E talvez por deixar asas à fantasia de cada qual, lhe tivessem alargado mais a legenda e a fama." (FONSECA, 1966:16), aqui o narrador caracteriza o Sr.
Paulo, sugerindo como ele aumentou sua fama, deixando espaços e vazios nas histórias de sua vida quando as narrava.

Esta "conversa" do narrador com o leitor está presente na narrativa e provoca a atmosfera de intimidade com a obra. O narrador, através dessa técnica, faz com que se tenha um nível de conhecimento profundo das personagens, tornando o leitor sensivelmente inserido no universo da narrativa e das personagens. Através de uma prosa poética, vemos a representação de todo o universo ficcional gerado na imaginação dos protagonistas, tornando um ermitão alguém muito maior do que sua figura representa na narrativa diante do mundo adulto, pois o narrador une-se ao ponto de vista das crianças, Pedro e Chinca, e expressa suas sensibilidades e seus autênticos olhares infantis, revelando toda a perspectiva ao modo surrealista, como nos ensinou Breton acima.

A título de exemplo desse tipo de narrador da ficção, mais próximo da intradiegese ${ }^{3}$, apresentamos o fragmento do conto "Um Peixe Gordo":

- Está bem. Chega para todas...

E passou adiante. Uma ainda lhe gritou:

- Eu pedi primeiro! Um peixe gordo!

Os peixes grandes é nos buracos que se apanham bem; ou à rede. No anzol não se pegam. Mas meter a mão num buraco de raízes estacarias ou loca de pedra, não é tão fácil como dizê-lo. Não porque esteja lá sempre uma rata peluda, de dente afiado, ou cobra assanhada, mas porque o Diabo também arma debaixo de água.

Mergulha-se no fundo onde é mais frio, e, com os olhos abertos, naquela luz esverdeada e baça da profundidade, procuram-se os buracos. (FONSECA, 1966:206-207).

$\mathrm{O}$ narrador discorre por mais alguns parágrafos explicando como ocorre a pesca feita por Pedro e Chinca, alertando os perigos e descrevendo cada etapa, além das maneiras que poderiam, ou não, obter sucesso na atividade, assim entendemos que se trata de uma narrativa dentro da "primária". ${ }^{4}$

Este envolvimento do narrador na ambientação descrita com tons poéticos, a intimidade com que ele descreve, caracteriza e opina na construção das personagens, sob a perspectiva infantil, faz com que o

\footnotetext{
Como explicam Aguiar e Silva: "Intradiegético - E aquele que ocupa a posição de narrador em uma narrativa secundária produzida no decurso de uma narrativa primária. Seu ato narrativo é interno em relação aos eventos narrados naquela narrativa”. (AGUIAR E SILVA apud FRANCO JR, 2009:41).

4 Assim atestamos a presença de um subtipo: "Hipodiegético - Subtipo do narrador intradiegético [...] é aquele que produz uma narrativa que se insere na narrativa primária, interrompendo-a, representando formal e funcionalmente uma narrativa dentro da narrativa." (Idem, ibidem).
} 
leitor partilhe o mundo fictício e lúdico que salta dos contos. Desta forma, os espaços tornam-se subsídios para a percepção surreal da obra de Branquinho da Fonseca, o fragmento abaixo, retirado das primeiras páginas do livro apresenta o mundo em que será fundado o enredo dos contos:

Pedro, de chapéu largo e alfanje à cinta, o Chinca mais modesto nas armas, que não passavam de navalha e fisga, mas obrigado a atar na cabeça o lenço vermelho, um a proa e outro à ré, com duas varolas que firmavam no fundo pedregoso do rio, levavam o barco contra a corrente, num manso deslizar de passeio ameno ou de quem vai para o longe e poupa forças. (FONSECA, 1966:13).

Pedro socialmente é superior a Chinca, característica perceptiva na primeira linha do fragmento e confirmada na continuidade da obra. $\mathrm{O}$ fato de eles levarem um barco contra a corrente remete à contrariedade, à transgressão das personagens, que estão: "contra a corrente, num deslizar de passeio ameno", assim, certamente, há algo que se opõe ao fluxo, que cria resistência.

Vale ainda ressaltar que a ação de conduzir o barco contra a corrente não parece ser compatível a um passeio ameno, uma vez que requer fisicamente um maior esforço, são forças opostas em ação num meio. Mas aqui não há uma contradição na escolha da forma pelo autor, desta maneira ele ressalta o caráter transgressor-inconsciente das personagens e assim, paulatinamente, constrói-se o ambiente do enredo e firma-se a visão de mundo de Pedro e Chinca, pois a manifestação do inconsciente de levar um barco de forma "mansa" contra as forças naturais manifesta o "ambiente" surrealista da ficção.

Ainda podemos destacar um elemento importante representado pela bandeira que as crianças utilizavam no barco, como descreve o fragmento que segue: "Era uma bandeira quadrada, que tinha ao centro, por suas mãos bordados a retrós branco, um pistolão de boca larga e uma espada recurva, mais imitante a alfanje moiro do que a durindana cristã". (FONSECA, 1966:11-12). A espada "moira" representa uma civilização que invadiu e habitou durante alguns séculos a península ibérica e foi, posteriormente, expulsa pelos cristãos. Sabidamente, os mouros fazem parte de uma civilização perseguida e negada historicamente, mas também constitutiva da identidade portuguesa. ${ }^{5}$

\footnotetext{
5 Benjamim nos diz que o homem atribui à experiência uma autoridade, sem deixar espaço para as diferenças que existem ao seu redor, e assim enclausura-se no seu próprio mundo onde apenas aquilo que ele julga como conhecimento cabe. Benjamim levanta esse questionamento: "E aqui está o segredo: uma vez que o filisteu jamais levanta os olhos para as coisas grandiosas e plenas de sentido, a experiência transformouse em evangelho." (BENJAMIN, 1928:22). No livro cristão, o filisteu é um materialista, com interesses vulgares e convencionais, também,
}

De certa forma, assim como uma civilização ou cultura oculta historicamente, as crianças são silenciadas e desvalorizadas pelo universo do adulto, logo podemos ver na escolha da heráldica da bandeira da embarcação infantil uma simbologia do caráter transgressor das personagens no âmbito da ficção, que só é assumida quando estas estão passando por momentos de paz e tranquilidade.

$\mathrm{O}$ universo transgressor das personagens crianças, quando em contato com o Senhor Paulo, perdura. Os meninos veem o velho ermitão como uma figura divina:

Com o ombro dorido, Pedro, dobrado para equilibrar a carga, apertava o passo, adivinhando o carreiro que, nas trevas, serpenteava entre a erva amarelada.

E, na imaginação, via o halo de luz que o velho irradiava no seu tugúrio, os olhos serenos e luminosos, as barbas brancas, e já ouvia aquela voz tranquila e bem pausada.

À luz frouxa dum aguço resinoso, espetado num buraco da parede negra, viu o velho sentado a um canto, e, do outro lado as cabeças de duas cabras, por detrás dumas varolas secas. (FONSECA, 1966:18-19).

No fragmento acima Pedro segue um caminho de trevas, escuro e tortuoso, até a cabana do "velho", nesta passagem vemos que o narrador descreve de maneira que o leitor construa a imagem de um lugar macabro. Porém, quando o foco narrativo é direcionado para o Sr. Paulo a imagem é descrita de forma oposta.

Através da imaginação do menino Pedro, descrita pelo narrador, observamos a divinização do velho, irradiando luzes, em postura serena, e está sentado do lado oposto das cabras, figuras estas que, segundo as crenças populares, remetem ao demônio. Este ambiente construído na narrativa compõe um paradoxo, a imagem de alguém que diante da criança pode representar uma figura divina, mas vive num universo de trevas, o qual pode ser comparado ao mundo repressor em que as personagens estão imersas, onde as crianças se tornam naturalmente transgressoras diante dos adultos e são constantemente oprimidas por estes.

Porém, Pedro e Chinca não consideram Paulo opressor, pelo contrário, o tratam como se o ermitão pertencesse "ao seu povo", haja vista que um dos motivos que podemos agregar a essa consideração é a profissão de circense que o velho teria: "[...] antigo acrobata e palhaço de grande circo [...]" (FONSECA, 1966:16), profissão

\footnotetext{
segundo o dicionário Houaiss, filisteu é o povo inimigo dos semitas, judeus, nômades e sabidamente habitantes da península Ibérica, expulsos junto aos mouros, os mesmos representados no brasão da bandeira preta. Ângelo Ariano Farias de Assis apresenta em seu artigo a presença destes povos na península em determinado espaço na história: "A presença hebraica na Península Ibérica encontra seus primórdios na Antigüidade. Indícios mostram ser de origem mais antiga do que a ocupação daquele espaço por mouros, godos e romanos". (ASSIS, 2003:02).
} 
nômade que escapa do tradicionalismo monótono, vivendo mais próximo do universo infantil, apresentado no fragmento:

- Não temos nada o que contar. O Sr. Paulo é que correu o Mundo todo e sabe muitas coisas.

- Muitas coisas que não valem nada. Gosto de ouvir os rapazes como vocês... para quem o Mundo é grande. Correr-lhe as estradas e fazê-lo pequeno... Depois tem de se parar num sítio qualquer, a lembrar e a sonhar, para o tornar a fazer grande. (FONSECA, 1966:20).

A proximidade entre as personagens é composta também pela oportunidade que o palhaço concede às crianças de apresentar suas experiências e compartilhálas, fazendo com que elas abaixem os escudos diante dos adultos. $\mathrm{O}$ embate de mundos, infantil/adulto, durante o diálogo com o ermitão é identificado quando Pedro fala sobre seu contato com o professor de música:

[...] dava-me vontade de rir a cara de espanto daquela espécie de professor, por eu perceber nada do que ele queria ensinar. [...] quando me vê na rua, até parece que tem medo. Fui eu quem lhe pôs o nome de "La-mi" [...]

O senhor não o conhece. É um palerma. Traz o rei na barriga, por tocar rabeca... (FONSECA, 1966:22).

A superioridade com que o adulto se produz diante da criança é notada no fragmento. Instituído da máscara, o adulto conserva sua autoridade. O léxico em destaque, "espécie", mostra a forma com que a personagem menospreza o professor, criando a barreira entre adulto/ criança e ensinante/ensinado.

Sobre este assunto, Breton escreve que o homem adulto: "Se conservar alguma lucidez, não poderá senão recordar-se da sua infância, que lhe parecerá repleta de encantos, por mais massacrada que tenha sido com o desvelo dos ensinantes" (BRETON, 1978:168), tal afirmação pode ser relacionada com o momento em que o senhor Paulo fala a Pedro, quando diz que muitas das coisas vividas não têm valor, e o aconselha a ouvir aquilo de quem observa e vive o mundo de forma grandiosa, fazendo das pequenas coisas algo muito maior, atreladas à imaginação que o universo infantil possibilita, mesmo que contido na indiferença do adulto, como Breton nos ensina.

Uma ideologia abordada pela atmosfera surrealista é a liberdade, como também atesta Breton: "[...] só o que me exalta ainda é a única palavra, liberdade" (BRETON, 1978:169), mas fica claro que Breton refere-se não só a liberdade física, mas a de opinião, de imaginação, o viver no universo palpável, porém gerado no contato do eu e mundo, resultando na maneira particular de cada um vivenciar seu universo, ou coletiva, quando outros também conseguem participar deste universo, como Pedro e Chinca o fazem na narrativa.

Walter Benjamim quando discute sobre a máscara do adulto, a qual a chama de experiência, visualiza nela não só uma forma de reprimir a criança, mas também uma forma de fechamento da vivência, pois o adulto esconde-se atrás dessa máscara, para o filósofo. $\mathrm{Na}$ narrativa analisada, isto que denominamos máscara do adulto apresenta-se na conversa de Pedro e o Sr. Paulo, quando este explica a arrogância do professor de musica constatada pelo menino.

É um pobre homem. Põe-se com ares de importância, para esconder a sua fraqueza, a sua angústia. Se ele sente que não vale nada, querias que o mostrasse a quem não lhe perdoava. Talvez quando esteja sòzinho tenha necessidade de chorar... (FONSECA, 1966:22).

A consciência das personagens no fato da opressão sofrida é representada na obra no momento em que Leonor iça uma bandeira neutra e retira a bandeira preta, como podemos observar no fragmento: "Leonor, solerte, baixou a bandeira preta e içou um pavilhão de um país neutro, o "Peru", nação e ave do melhor e sorridente aceite em toda costa" (FONSECA, 1966:13). As crianças assim fazem uso do símbolo de um país que é bem aceito dentro do universo criado por elas.

Segundo Breton e Benjamin, a experiência do homem e suas certezas faz com que ele limite a sua existência, e isto se reflete em todo o universo a sua volta, e é esta postura que vitimiza Jurro, no conto homônimo, como podemos observar no fragmento abaixo:

Do pai, com famas de ladrão de estrada, falava-se a medo e ninguém tinha provas.

Era baixo, de cara negra, a cabeça grande, enterrada entre os ombros quadrados, os olhos pequenos, como de rato, a luzirem no fundo dos dois buracos, por cima da boca quadrada com quatro filas de dentes [...] que rangiam. Tinha os braços curtos e as mãos grandes.

A uns bons-dias respondia com um grunhido rouco. [...] Matara um homem, mas de caras, dentro da quinta, legalmente.

Mesmo quando sorria, o sorriso naquela face parecia um esgar de ameaça. E todos se afastavam, ninguém o aceitava. Tinham medo. Mas não havia razão. Cá fora, nos caminhos de toda a gente, era ele quem tinha medo. (FONSECA, 1966:163-164).

Jurro é caracterizado com uma imagem zoomórfica. $\mathrm{O}$ preconceito que o antagonista sofre é fortemente marcado pela sua aparência, como uma herança recebida do pai. Todos ao redor de Jurro estão revestidos pela máscara que 
os impedem de perceber o sentimento no discriminado. No momento que o associam a um animal, o afastam, e isto faz com que Jurro feche-se em seu mundo, não por vontade própria, mas por conta daqueles que perderam sua sensibilidade, e assim condenam toda uma família ao preconceito.

Jurro, nos diz o narrador, demonstra sensibilidade, mas ela é retraída pela atitude do seu interlocutor, como podemos constatar a seguir:

E, apesar de tudo, sua boca torcia-se, por vezes, num sorriso que pretendia ser de simpatia humana e de comunicação. Se o acaso o fazia deparar com alguém que não fugia, o Jurro tinha um olhar brilhante de ansiedade e a boca alargava-se-lhe num começo de riso, como se, enfim encontra-se um amigo no deserto que era a sua vida. Porém nessa expressão ninguém via o que ela queria dizer, mas só o que pensavam daquele homem. [...] A casca da sua cara era impermeável a simpatia que sentia dentro de si. (FONSECA, 1966:164-165).

Jurro tornou-se o que as pessoas o fizeram tornar-se, o moldaram ao ser que se difere do Sr. Paulo, este antes de permitir que a "experiência" dos adultos o rotulasse, retirou-se e, apesar de viver de doações, manteve o olhar sensível sobre as coisas. Pedro, quando vai diante de Paulo, nos mostra que não é influenciado pelo julgamento dos adultos. Ao contrário, já no conto "Jurro", Pedro não cria resistência em absorver aquilo que é julgamento das pessoas à respeito de Jurro:

$\mathrm{E}$ as abelhas zumbiam de flor em flor, mas não era só delas aquele mundo. Outros voadores passeavam pelo jardim maravilhoso, poisavam nas belas pétalas e entonteciam de seus aromas e bebiam de seus licores e trincavam suas carnes [...] Pedro arrastava-se sobre a erva [...] Ficou imóvel [...] E neste momento viu uma bota que lhe pisou a mão. Ia gritar, mas olhou para cima: O Jurro. A voz estrangulou-se-lhe na garganta. O Jurro abria a boca a rir (FONSECA, 1966:167).

A cena surge descrita em uma linguagem poética, pois o modo como o narrador apresenta o cenário natural, atribuindo à natureza licores e carnes, a antropomorfiza, e aponta para uma estética surrealista uma vez que a personagem interage com o meio num estado poético. Esta simbiose é quebrada por Jurro, pois Pedro ao confrontar-se com a figura do antagonista fica perplexo, isso é comprovado através do narrador, quando este descreve a reação do menino e coloca em focoo Jurro.

O reflexo da discriminação se reflete na sociabilidade do antagonista: "mas de repente teve uma expressão de surpresa e de arrependimento. Abriu a boca como se fosse pedir desculpa, mas as palavras não saíram."
(FONSECA, 1966:168). Jurro embora tenha consciência da sua atitude errônea, não consegue falar. A sociabilização expressa através da linguagem é reprimida em Jurro, a animalização atribuída ao antagonista, não permitindo a comunicação verbal com outros, o transformou externamente, aparentemente, em um ser insensível.

Pedro e Chinca já estão neste conto na transição da infância para a adolescência, pois ainda notamos a sensibilidade infantil demonstrada em alguns momentos, mas agora esta começa a ser corrompida pela cultura a que estão assujeitados. Pedro está nessa transitoriedade quando questiona Jurro: "Pedro crescendo em autoridade e revolta, continuou: - Porque é que me pisou a mão." (FONSECA, 1966:168). Porém, logo o protagonista vive uma confusão psicológica diante da figura de Jurro, demonstra a incerteza da sua posição tomada em relação ao antagonista: "Da atitude de Jurro tinha-lhe ficado uma impressão confusa. Chegou a parecer-lhe que tinha feito aquilo por brincadeira e que ficara triste de o ter magoado. Ou era doido e mau?" (FONSECA, 1966:169). De certa forma, essa passagem atesta que Pedro ainda é dotado do olhar infantil, conseguindo penetrar a "casca" do outro, mas está sofrendo a metamorfose que a vida adulta condiciona.

Chinca, por sua vez, não penetra esta "casca" e ainda julga o ato de Jurro quando demanda ao amigo: "- Dar-lhe uma pedrada nos cornos." (FONSECA, 1966:171), e assim ambos acabam agredindo Jurro, deixando-o cego de um dos olhos, e tomando ainda a arma do ferido:

Pedro ficou de fisga aperrada, como besteiro que aguarda a vez de disparar. [...] ... Deu-lhe numa vista?... [...] O Jurro não respondia, com as mãos a tapar a cara, soltando uns roncos abafados [...] abrindo o outro olho viu a espingarda nas mãos do rapaz [...] (FONSECA, 1966:173).

Jurro, desacreditado da possibilidade de que alguém possua compaixão por ele, torna-se vítima do preconceito que sempre sofrera, a sua justificada falta de confiança no próximo, e a constante marginalização a qual é imposto, custa-lhe a vida. $\mathrm{O}$ antagonista segue pela rua não alcoolizado, mas alegre, como nos conta o narrador, após sair da delegacia, para onde foi levado por Pedro e Chinca, chegando até a taberna onde, desacreditado e discriminado, morre:

O taberneiro empurrou-o e ele escorregou e caiu. Foi o Zé Borba quem lhe estendeu a mão para o ajudar a levantar-se. Em troca recebeu uma cabeçada no peito, que o atirou contra a parede. Sobre a mesa estava uma faca de cortar chouriço , aguçada [...] E o Jurro tirou do bolso a navalha [...] o Zé Borba. Ficou com uma cicatriz no braço. Mas o Jurro - nunca mais meteu medo a ninguém. (FONSECA, 1966:176). 
Para Schlegel, segundo Paz, é tarefa "tornar poética a vida e a sociedade" (PAZ, 1996:86) - Otávio Paz cita esta passagem em sua obra quando discute as semelhanças entre o programa Romântico e o Surrealista - podemos afirmar que isto vai ao sentido inverso do que acontecera na sociedade em que Jurro vivera. A discriminação leva Jurro à morte e, de certa forma, compreendemos que isto simboliza não somente a morte física, pois toda leitura limitada do outro, todo o julgamento, leva à morte também do outro como diferente, bem como da visão poética da vida e da sociedade.

Pedro passa para a idade adulta, Chinca, como Pedro, já não é mais criança, porém não era letrado, assim a diferença social, que já revelamos na análise do primeiro conto, agora se aprofunda, nesta altura, a convivência entre os dois já não era constante, como podemos constatar no momento em que Chinca encontra a "velha Nau Falcão":

O Chinca devia estar farto de esperar. [...] $\mathrm{O}$ barco a velha "Nau Falcão", de fundo para o ar, mostrava o limoso das tábuas podres. Com lentidão, como se estivesse ainda a pensar noutra coisa, abaixouse, deitou-lhe as mãos a borda, e, devagar virou-o. [...] Começou a remar contra a corrente, grossa das primeiras chuvas. (FONSECA, 1966:205).

Várias outras personagens influenciam diretamente nas ações dos protagonistas e suas personalidades, como as lavadeiras que indicam ao leitor que Pedro e Chinca perderem o olhar infantil diante do sexo oposto, aflorando sentimentos antes desconhecidos por eles. ${ }^{6}$ No conto "Um Peixe Gordo", Pedro começa a interessar-se por Lídia, por sua vez, Chinca tem um olhar desejoso por Rosa, ambos saem à busca dos peixes para agradar às jovens, porém nesse desejo de realizar o desejo alheio não encontram o amor, mas a escuridão da morte:

Tinha chegado ao sítio combinado. O Chinca ou estava a dormir ao fresco da sombra, ou fora-se embora.

\footnotetext{
6 O surrealismo não transita apenas pela inocência da criança, a sensibilidade dela faz-se necessária para a manifestação surrealista. Vale destacar também que a mulher é uma das peças centrais desse estilo, não o ser, mas a simbologia a qual a figura feminina remete. A sensualidade, o erotismo, são elementos presentes na literatura e nas artes plásticas surrealistas, aliada ao amor e ao desejo que suscita. Sobre isso Otávio Paz afirma: "O amor e a mulher ocupam... um lugar central: a plena liberdade erótica alia-se a crença no amor único. A mulher abre as portas da noite e da verdade; a união amorosa é uma das experiências mais altas do homem e nela o homem toca as vertentes do ser: a morte e a vida, a noite e o dia" (PAZ, 1996:86). Dessa forma o estado amoroso faz com que os sujeitos passem a estarem mais propícios à leitura poética do mundo, assim podemos compreender a mulher como símbolo marcante do desejo e do erotismo, e a união desses elementos permite que a faceta poética do surrealismo perdure e manifeste-se na vida adulta. Porém, o que Chinca tem não é amor, mas uma relação de interesse, pois lembremos que Rosa troca a sua atenção por uma truta, antes também fez Chinca prometer que iria trabalhar em uma fábrica.
}

Chinca!...

Não respondeu. Ao longe, no sino da igreja bateu uma badalada. Afinal vinha atrasado só meia hora. Uma coisa branca chamou-lhe a atenção debaixo da água, junto a margem. Era o Chinca ao mergulhar os buracos... Mas de repente pôs-se de pé, olhou melhor: estava parado. [...] Os serenos espelhos em que os salgueiros se reflectiam turvou-se numa tempestade de pequenas ondas [...] Agarrou-se-lhe ao braço preso no buraco, fincou os pés na margem e, num esticão brutal, puxou-o como quem arranca uma estaca da terra. [...] Estava morto. [...] Era a que tinha dito: - Pedi primeiro! Um peixe gordo... (FONSECA, 1966:207-208-211).

O narrador marca com a linguagem surrealista a relação da "inserção do sujeito no objeto" (PAZ, 1996:86), quando descreve Pedro no barco e Chinca deitado nele: "Meteu-se no barco que o corpo atravancava da proa à ré e agarrou nos remos que lhe pareceram dum bater pesado e triste como asas mortas. [...] Tinha virado o barco e agora descia lentamente ao sabor das águas." (FONSECA, 1966:210). A relação das personagens com o meio faz parte da estética surrealista, é possível compreender a imagem dos remos como "assas mortas", simbolizando o fim da liberdade que os garotos viviam naquele ambiente que, agora com a morte de Chinca, não existe mais, pois antes contracorrente, agora a embarcação desce a favor da corrente. Dessa forma, a transgressão e o confronto com o universo do adulto encerram, e podemos relacionar isto ao fato de Pedro tornar-se adulto.

A bandeira, símbolo presente no título da obra e na embarcação das crianças, como já vimos, representa, através da leitura da heráldica, povos que foram reprimidos em determinado espaço e momento na história, e pode ter relação com as personagens infantis, oprimidas pelo universo do adulto, bem como com a própria história política de Portugal, que passava por um regime fascista na época de publicação de Bandeira Preta.

O Estado Novo em Portugal foi um governo com ideologias repressivas, e sabe-se que o desejo de liberdade é uma constante em um povo reprimido. A relação de Fonseca com a revista Presença buscava em suas ideologias a liberdade, e embora o autor tenha rompido com o grupo da revista citada, manteve em sua obra a posturas estéticas de influência surrealista.

A libertação da máscara que reveste o adulto, chamada de "experiência", é apresentada em vários momentos, como na conversa das personagens infantis com o antigo palhaço e acrobata Paulo e em "Jurro", através da indiferença e discriminação a qual a personagem título é exposta. Com a passagem da infância para a 
adolescência, as crianças vão perdendo a sensibilidade e o lirismo com que observavam o mundo, passando assim, como Pedro, a sofrer uma confusão psicológica em relação à personalidade de Jurro. Pedro foi perdendo gradativamente a potência da infância até o ponto de afastar-se de Chinca e quando buscou reatar o vínculo já não havia mais como fazê-lo.

Para Breton, o "surrealismo, o novo modo de expressão pura..." propõe a libertação de um mundo condicionado por regras impostas pelo racionalismo, pela visão utilitarista da vida e suas ideologias discriminatórias, para isto acontecer seria preciso antes olhar o mundo de forma a penetrar as barreiras construídas pela "experiência". Viver ou reviver a infância e seu olhar diante ao universo seria um bom começo.

Enfim, os contos de Branquinho da Fonseca, em sintonia ao programa surrealista, propõem a reflexão sobre a postura diante da vida, ou sobre uma nova possibilidade de recontá-la. Mas, ao final do último conto, abaixar a "Bandeira Preta", que no início da obra representava o "viver o sonho", significa, de certa forma, deixar de viver outra história, (de liberdade de um regime totalitário ainda não alcançada por Portugal? De liberdade de um regime de opressão política, econômica e cultural ainda não alcançada pelas ex-colônias africanas?), a que foi negada ou silenciada pelos anos de autoritarismo. Lembremos novamente do símbolo mouro na bandeira hasteada no primeiro conto, esta mesma bandeira minguada ao fim do livro só pode representar o luto, ou a morte da luta das personagens infantis contra a "máscara do adulto", máscara esta que não parece diferir da máscara do tirano ou do colonizador.

\section{Referências}

ASSIS, Ângelo Ariano Faria de. O Medievo Português em tempos de livre crença: relações entre judeus e cristãos em Portugal antes do monopólio católico iniciado em 1497. Revista Mirabilia, n. 3, p. 212-241, dez. 2003. Disponível em: $<$ http://www.revistamirabilia.com/sites/default/files/pdfs/ 2003_11.pdf $>$. Acesso em: 18 out. 2013.

BENJAMIN, Walter. Reflexões sobre a criança, o brinquedo e a educação. São Paulo: Duas cidades/Editora 34, 2002.

BENJAMIN, Walter. O surrealismo - o último instantâneo da inteligência europeia. Magia, técnica, arte e política. São Paulo: Brasiliense, 1994.

BRETON, André. Manifesto Surrealista (1924). In: TELES, Gilberto de Mendonça (Org.). Vanguarda europeia e modernismo brasileiro. Rio de Janeiro: Vozes, 1978. p. 168-202.

DIAS, Fernando Paulo. A teoria da "Presença". Idearte - revista de teorias e ciências das artes, v. 6, 2010. Disponível em: $<$ http:// www.idearte.org/texts/68.pdf>.

FADDA, Sebastiana. Verbete sobre Branquinho da Fonseca. In: BOAVIDA, Maria Filomena; FRAZÃO, Fernanda. Pequeno dicionário de autores de Língua Portuguesa. Lisboa: Amigos do Livro Editores, 1983. p. 176.

FONSECA, Branquinho da. Bandeira Preta. Lisboa: Ed. Portugália, 1966.

HOUAISS, Antônio. Dicionário Houaiss da Língua Portuguesa. São Paulo: Objetiva, 2001.

MOISÉS, Massaud. Branquinho da Fonseca. A literatura portuguesa. São Paulo: Cultrix, 2008. p. 368-369.

PAZ, Octavio. O verbo desencarnado. Signos em rotação. São Paulo: Perspectiva, 1996. p. 75-94.

Recebido: 21 de outubro de 2014 Aprovado: 19 de fevereiro de 2015 Contatos: kelipacheco@hotmail.com marcelowwm@bol.com.br 